\title{
ADSORPTION OF Pb(II) BY POLYANILINE/SILICA GEL COMPOSITE: KINETICS AND ISOTHERM STUDIES
}

\author{
Mas Inda Putrinesia ${ }^{1^{*}}$, Nurlina ${ }^{1}$, Winda Rahmalia \\ Jurusan Kimia, Fakultas MIPA, Universitas Tanjungpura, Kalimantan Barat, Indonesia \\ "Corresponding author: indaputrinesia0908@student.untan.ac.id
}

\begin{tabular}{l}
\hline ARTICLE INFO \\
Article history: \\
Received 25 October \\
2018 \\
Accepted 17 \\
November 2018 \\
Available online \\
30 December 2018 \\
Keywords: \\
Antioksidan,Citrus \\
microcarpa Bunge, \\
Limonin, Triterpenoid \\
\end{tabular}

\begin{abstract}
Research on the study of kinetics and isotherm adsorption of $\mathrm{Pb}$ (II) by polyaniline/silica gel (PANI/ $\mathrm{SiO}_{2}$ ) composite from glass waste has successfully been done. The polymerization of silica gel was prepared by sol-gel process. Meanwhile, $\mathrm{PANI} / \mathrm{SiO}_{2}$ composite was prepared using sulfuric acid $\left(\mathrm{H}_{2} \mathrm{SO}_{4}\right)$ as its dopants and hydrogen peroxide $\left(\mathrm{H}_{2} \mathrm{O}_{2}\right)$ for oxidation process. Composition of oxide compound in $\mathrm{PANI} / \mathrm{SiO}_{2}$ composite was analyzed by X-Ray Fluorosence (XRF) and Gas Sorption Analyzer (GSA). Adsorption of $\mathrm{Pb}$ (II) was carried out by contacting $\mathrm{PANI} / \mathrm{SiO}_{2}$ with $\mathrm{Pb}\left(\mathrm{NO}_{3}\right)_{2}$ solution for $20,40,60$ and 80 minutes, with concentrations of $150,200,250,300,350$ and 400 $\mathrm{mg} / \mathrm{L}$. The optimum contact time was reached at 40 minutes. This adsorption followed pseudo-second order model with $\mathrm{R}^{2}=0.996$. The first optimum adsorption capacity was reached in the concentration of $250 \mathrm{mg} / \mathrm{L}$. Isotherm adsorption followed Langmuir models with $\mathrm{R}^{2}=0.954$ (monolayer capacity $=51.02 \mathrm{mg} / \mathrm{g}$ ).
\end{abstract}

(C) 2018 IJoPAC. All rights reserved

\section{Introduction}

Heavy metal pollution is one of the most concerned environmental problems nowadays. Lead $(\mathrm{Pb})$ is one of heavy metals that are present in the environment. In water, $\mathrm{Pb}$ is present as divalent ion $\mathrm{Pb}$ (II). These metal ions are released to water environment by many activities like mining, manufacturing, and farming ${ }^{[1]} . \mathrm{Pb}$ (II) is carcinogenic, harmful to liver, kidneys, and could cause abnormalities on pregnant women's babies ${ }^{[2]}$. There are many ways to reduce concentrations of $\mathrm{Pb}$ (II) in water such as precipitation, coagulation, ion exchange and adsorption. However, adsorption is more simple way to do ${ }^{[3 ; 4]}$. Nowadays, research about adsorbent in combination of organic-inorganic polymeric materials have gained much attention for the removal of heavy metals. Polyaniline (PANI) is one of organic conducting polymer with electrical properties that are tunable by doping ${ }^{[5]}$. In addition, PANI can be used as an electrode material, electrochromic device, recodable optical disk ${ }^{[6]}$. As a polymer, PANI can be produced as a film ${ }^{[6]}$ and powder ${ }^{[3 ; 5]}$. As an adsorbent, PANI has the lone pair of electrons on nitrogen atoms that can make a coordinate bond with positive metal ions ${ }^{[3]}$ In many applications, PANI is recommended to be combined with inorganic materials because of its weaknesses (has low thermal stability and does not have good stability with the change of $\mathrm{pH}$ ). Meanwhile, among 
various inorganic materials, silica gel has gained more attention due to its large surface area, high porosity, has good stability in a wide range of $\mathrm{pH}$, etc ${ }^{[3 ; 4]}$.

Silica gel can be extracted from mineral like quartz. But, taking minerals countinously can damage the enviroment. Extracting silica from renewable natural materials or from waste is one of the wisest ways. Glass waste is material that contains up to $70 \%$ silicon dioxide ${ }^{[7]}$. The utilization of glass waste in the making of silica gel is expected to change the use of minerals that are not renewable. The presence of glass waste in the environment is quite high given the fact that glass is used for buildings, furnitures, beverage bottles and other industries. Glass waste will be processed into sodium silicate. Sodium silicate will be polymerized onto silica gel by adding sulfuric acid in sol-gel process. After that, silica gel will be composited with PANI.

This study will focus on the kinetics and isotherm adsorption of solution contained $\mathrm{Pb}$ (II) metal ions. The adsorption process was carried out by contacting the composite in solution of $\mathrm{Pb}\left(\mathrm{NO}_{3}\right)_{2}$ with variation of contact time and variation of concentraton.

\section{Materials and Methods}

\subsection{Materials}

Glass waste was taken from glass cutting factory in Kubu Raya, West Kalimantan. Aniline $\left(\mathrm{C}_{6} \mathrm{H}_{5} \mathrm{NH}_{2}\right)$ ACS reagent, $\geq 99,5 \%$ was supplied by Sigma-Aldrich (Germany). Analytical grade hydrochloric acid $\mathrm{HCl}, 37 \%)$, sulfuric acid $\left(\mathrm{H}_{2} \mathrm{SO}_{4}, 96 \%\right)$, sodium hydroxide $(\mathrm{NaOH})$ reagent grade, $\geq 98,0 \%$ pellets (anhydrous), hydrogen peroxide $\left(\mathrm{H}_{2} \mathrm{O}_{2}\right)$, ferrosulfate (pentahydrate) $\left(\mathrm{FeSO}_{4} \cdot 7 \mathrm{H}_{2} \mathrm{O}\right)$ pellets and lead dinitrate $\mathrm{Pb}\left(\mathrm{NO}_{3}\right)_{2}$ pellets were supplied by Sigma-Aldrich, Germany

\subsection{Methods}

\subsubsection{Preparation of silica gel from glass waste}

Glass waste was cleaned and dried before destructed. The fine glass then sieved ( 80 mesh). Then, 100 grams of fine glass powder was added into $300 \mathrm{~mL}$ of $\mathrm{NaOH}$. The mixture was stirred and heated until most of the water evaporated. Then, it was heated by furnace at $400^{\circ} \mathrm{C}$ for 4 hours. After that, sodium silicate in the solid phases was added into $500 \mathrm{ml} \mathrm{H}_{2} \mathrm{O}$ and stirred for 3 hours $\left(100^{\circ} \mathrm{C}\right)$. At the end, this process will produce sodium silicate solution.

Hydrochloric acid (3M) then dropped into $100 \mathrm{ml}$ of sodium silicate solution while stirring until the gel was obtained. The hydrogel was then dried in the oven at $80^{\circ} \mathrm{C}$ for 18 hours. The form of dry silica (xerogel) then produced. Silica xerogel was crushed and washed with $\mathrm{H}_{2} \mathrm{O}$ until it was neutral. Xerogel powder was dried in the oven at $80{ }^{\circ} \mathrm{C}$ to make neutral silica xerogel ${ }^{[8]}$.

\subsubsection{Polymerization of polyaniline/silica gel composite}

Silica gel 2.6 grams were heated for 3 hours $\left(110^{\circ} \mathrm{C}\right)$ to activate its surface. Meanwhile, 0.4 M sulfuric acid $250 \mathrm{ml}$ was prepared, then stirred using magnetic stirer. While it was being stirred, the activated silica was inserted into the beaker slowly. The system then kept stirring for about 2-3 hours until it was homogeneous. Then, 3.2 grams of aniline was added to the system. When it was added, the system should be in cold condition $\left(4-5^{\circ} \mathrm{C}\right)$. The system was constantly stirred until homogeneous. After that, 3 grams of hydrogen peroxide was added into system and let the system strirred for 30 minutes. The last addition was adding about two drops of ferronium sulfate pentahydrate. Then the system was stirred at room temperature for 24 hours. The precipitate was formed, then filtered and washed using sulfuric acid and acetone ${ }^{[9]}$. Polyaniline/silica gel composite was characterized using XRF. 


\subsubsection{Determination of kinetica adsorption}

A total of 0.1 gram of polyaniline/silica gel composite were added to $25 \mathrm{ml} \mathrm{Pb}$ (II) solution at a concentration of $200 \mathrm{mg} / \mathrm{L}$. Both were contacted with contact time variations of $0,20,40$, 60 and 80 minutes. After that, the system was filtered and the filtrate ras taken. Repeated the experiment for 3 times. Analyzed concentration of $\mathrm{Pb}$ (II) using AAS. The determination of the adsorption reaction kinetics then was calculated by equation $(2.1)-(2.4)^{[10]}$.

First Order kinetics equation $\quad: \ln C_{e}=-k_{1} t+\ln C_{o}$

Second Order kinetics equation $\quad: \frac{1}{C_{e}}=k_{2} t+\frac{1}{c_{0}}$

Pseudo first Order kinetics equation $\quad: \log \left(q_{e}-q_{t}\right)=\log q_{e}-\frac{k_{3}}{2,303} t$

Pseudo second Order kinetics equation $: \frac{t}{q t}=\frac{t}{q_{e}}+\frac{1}{k_{4} \cdot q_{e}^{2}}$

\subsubsection{Determination of isotherm adsorption}

Adsorption was carried out by variation of concentration of sample solution 150, 200, $250,300,350$ and $400 \mathrm{mg} / \mathrm{L}$. A total of 0.1 grams of polyaniline/silica gel adsorbent was added to $20 \mathrm{~mL}$ of a solution containing $\mathrm{Pb}$ (II) ions. The sample then was contacted with composite using a shaker (153 rpm) for 40 minutes. After that, the solution was filtered. The filtrate was taken and analyzed using AAS. The experiment was done for 3 times of repetitions. Determination of maximum adsorption capacity was calculated using Langmuir isotherm equation (2.5)-(2.8). Freundlich isotherm was calculated using equation (2.9) ${ }^{[11]}$.

$$
\begin{aligned}
& \frac{C_{e}}{q_{e}}=\frac{1}{b Q_{o}}+\frac{C_{p}}{Q_{o}} \\
& q_{e}=Q_{o}-\frac{q_{e}}{b C_{e}} \\
& \frac{Q_{e}}{q_{e}}=b Q_{o}-b q_{e} \\
& \frac{1}{q_{e}}=\frac{1}{Q_{o} \cdot b \cdot C_{e}}+\frac{1}{Q_{e}} \\
& \log q_{e}=\log k_{f}+\frac{1}{n} \log C_{\mathrm{e}}
\end{aligned}
$$

\section{Result and Discussion}

The oxide compounds in PANI/SiO ${ }_{2}$ was showed in Table 1.

Table 1. Composition of Oxide Compounds in $\mathrm{PANI} / \mathrm{SiO}_{2}$ Composite

\begin{tabular}{lc}
\hline \multicolumn{1}{c}{ Senyawa Oksida } & Persentase (\%) \\
\hline Silicon dioxide $\left(\mathrm{SiO}_{2}\right)$ & 89,11 \\
Titanium dioxide $\left(\mathrm{TiO}_{2}\right)$ & 0,003 \\
Aluminium dioxide $\left(\mathrm{Al}_{2} \mathrm{O}_{3}\right)$ & 1,029 \\
Iron (III) oxide $\left(\mathrm{Fe}_{2} \mathrm{O}_{3}\right)$ & 0,047 \\
Calcium oxide $(\mathrm{CaO})$ & 0,190 \\
Magnesium oxide $(\mathrm{MgO})$ & 0,198 \\
Potassium oxide $\left(\mathrm{K}_{2} \mathrm{O}\right)$ & 0,055 \\
Diphosphorus pentoxoxide & 1,045 \\
$\left(\mathrm{P}_{2} \mathrm{O}_{5}\right)$ & 0,005 \\
Chromium (III) oxide $\left(\mathrm{Cr}_{2} \mathrm{O}_{3}\right)$ & 0,014 \\
Chlorine $(\mathrm{Cl})$ & \\
\hline
\end{tabular}


Composite of $\mathrm{PANI} / \mathrm{SiO}_{2}$ contains up to $89 \%$ of silicon dioxide. It means that silica from synthesized glass waste has high purity. Other oxide componds were stand no more that $2 \%$, such as aluminium dioxide $\left(\mathrm{Al}_{2} \mathrm{O}_{3}\right)$ and diphosphorus pentoxoxide $\left(\mathrm{P}_{2} \mathrm{O}_{5}\right)$.

Composite was also characterized by GSA to measure its pore size. The volume mikropori is $0.014 \mathrm{cc} / \mathrm{g}$, with $48.570 \mathrm{~m}^{2} / \mathrm{g}$ surface area and the pore radius is $19.112 \AA$. It is can be certain that the composite is able to adsorb $\mathrm{Pb}$ (II) ion which the radius size is 1.22 .

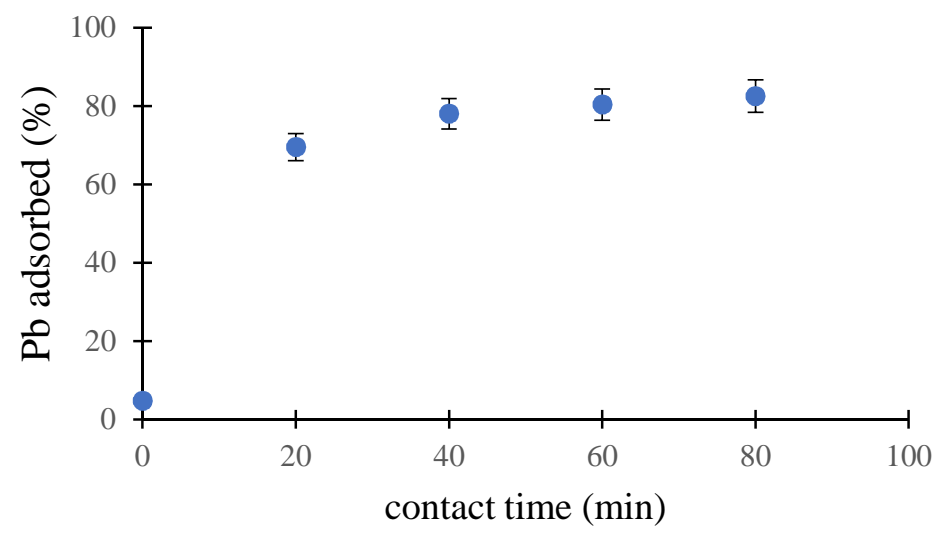

Figure 1. Effect of contact time on adsorption of $\mathrm{Pb}(\mathrm{II})$ using $\mathrm{PANI} / \mathrm{SiO}_{2}$ composite

Table 2. Adsorption Kinetic Parameters for the Adsorption of $\mathrm{Pb}(\mathrm{II})$ on $\mathrm{PANI} / \mathrm{SiO}_{2}$

\begin{tabular}{clc}
\hline Kinetic Models & \multicolumn{1}{c}{ Parameter } & Value \\
\hline \multirow{2}{*}{$1^{\text {st }}$ Order } & $\mathrm{k}_{1}\left(10^{-2}\right)(1 / \mathrm{min})$ & $-1,92$ \\
& $\mathrm{R}^{2}$ & 0,772 \\
\hline \multirow{2}{*}{$2^{\text {nd }}$ Order } & $\mathrm{k}_{2}\left(10^{-2}\right)(\mathrm{g} / \mathrm{mg} \cdot \mathrm{min})$ & 0,03 \\
& $\mathrm{R}^{2}$ & 0,897 \\
\hline \multirow{3}{*}{ Pseudo-first Order } & $\mathrm{q}_{\mathrm{e}}(\mathrm{mg} / \mathrm{g})$ & 1,367 \\
& $\mathrm{k}_{1}\left(10^{-2}\right)(1 / \mathrm{min})$ & 0,074 \\
& $\mathrm{R}^{2}$ & 0,125 \\
\hline \multirow{3}{*}{ Pseudo Order } & $\mathrm{q}_{\mathrm{e}}(\mathrm{mg} / \mathrm{g})$ & 37,453 \\
& $\mathrm{~h}(\mathrm{mg} / \mathrm{g} \cdot \mathrm{min})$ & 17,450 \\
& $\mathrm{k}_{2}\left(10^{-2}\right)(\mathrm{g} / \mathrm{mg} \cdot \mathrm{min})$ & 1,244 \\
& $\mathrm{R}^{2}$ & 0,996 \\
\hline
\end{tabular}

$\mathrm{q}_{\exp }=34,202$

The effects of contact time on the amount of $\mathrm{Pb}(\mathrm{II})$ adsorbed onto $\mathrm{PANI} / \mathrm{SiO}_{2}$ were investigated. In the first minute until 20 minutes, the curve increased sharply. In the periode of 20-40 minutes, the increase of $\mathrm{Pb}$ (II) that is adsorbed starts to ramp. This data then calculated by statistical product and service solutions (SPSS) with Duncan Methode. From this calculation, the increasing in 40-60 minutes was not significantly different. When the increase was not significantly different, it can be admitted as equilibrium phase of adsorption. The equilibrium contact time then is used for next adsorption. 


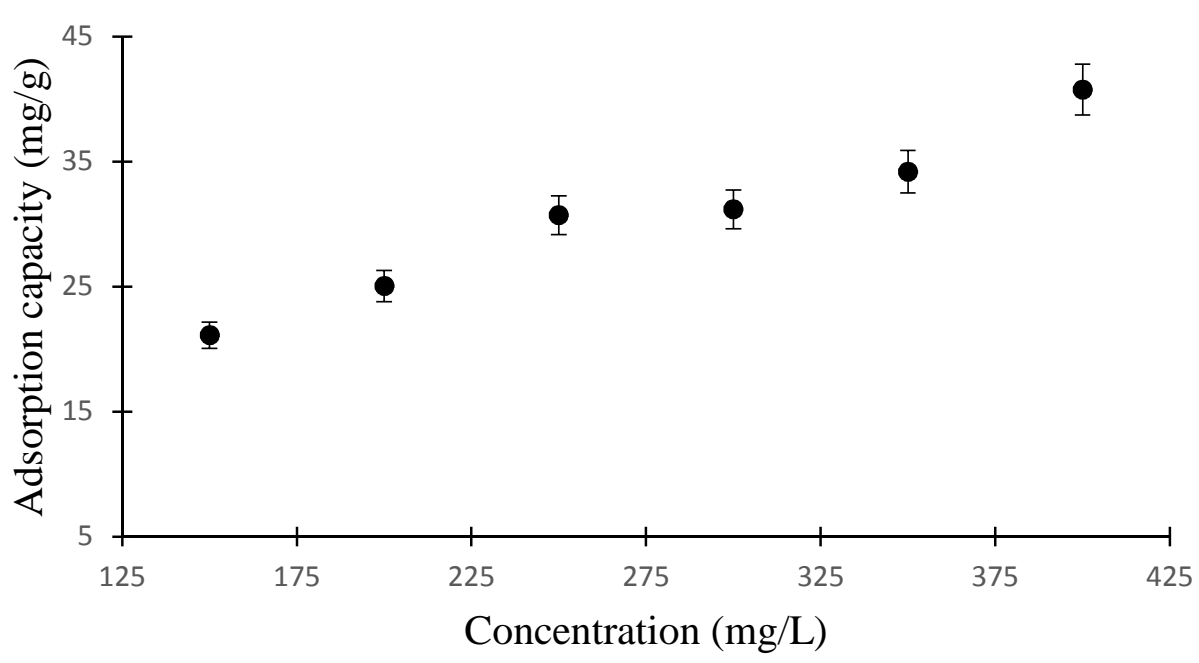

Fugure 2. Effect variation of concentration to adsorption capacity

Table 3. Adsorption Isotherm Parameters for the Adsorption of $\mathrm{Pb}$ (II) on $\mathrm{PANI} / \mathrm{SiO}_{2}$

\begin{tabular}{ccc}
\hline \multirow{2}{*}{ Persamaan Isoterm } & Parameter & Nilai \\
\cline { 2 - 3 } Langmuir & $\mathrm{b}(\mathrm{l} / \mathrm{mg})$ & 0,013 \\
\cline { 2 - 3 } & $\mathrm{Q}_{\mathrm{o}}(\mathrm{mg} / \mathrm{g})$ & 51,02 \\
\cline { 2 - 3 } & $\mathrm{R}^{2}$ & 0,954 \\
\hline \multirow{2}{*}{ Freundlich } & $\mathrm{E}_{\mathrm{ads}}(\mathrm{KJ} / \mathrm{mol})$ & 10,76 \\
\cline { 2 - 3 } & $\frac{K_{f}\left[(\mathrm{mg} / \mathrm{g})(1 / \mathrm{mg})^{1 / \mathrm{n}}\right]}{\mathrm{n}}$ & 0,083 \\
\cline { 2 - 3 } & $\mathrm{R}^{2}$ & 0,470 \\
\hline & $\mathrm{E}_{\mathrm{ads}}(\mathrm{KJ} / \mathrm{mol})$ & 0,943 \\
\hline
\end{tabular}

Adsorption process depends on the contact time between adsorbent and adsorbate. The determination of adsorption kinetics models is performed to determine the variables involved in the adsorption process. In addition, the kinetics model is required to predict the rate when adsorbate was adsorbed onto adsorbent ${ }^{[10]}$. A value of determination coefficient $\left(\mathrm{R}^{2}\right)$ showed the most suitable kind of kinetics. Adsorption capacity (qe) which is the most appropriate to the adsorption capacity of the research (qexp) showed the suitable kinetics model too. The value of adsorption parameters showed in Table 2 .

Based on Table 2, adsorption process followed pseudo-second order with the highest value of $\mathrm{R}^{2}=0.996$. It means that $99.6 \%$ data can be explained by pseudo-second order kinetic model ${ }^{[12]}$. Furthermore, the calculated of adsorption capacity from equation (qe) in pseudo-second order model has the closest value to the adsorption capacity based on the research. The initial adsorption rate at $\mathrm{t} \rightarrow 0(\mathrm{~h})$ was $17.45 \mathrm{mg} / \mathrm{g}$.min. Pseudo Order 2 states that the adsorption rate is equivalent to the quadratic concentration of adsorbate ${ }^{[12]}$. So, if the concentration of adsorbate increases twice as much, then the adsorption rate will increase.

Initial concentration of $\mathrm{Pb}$ (II) effected to quantity of $\mathrm{Pb}$ adsorbed at equilibrium (Figure 2). The conection between initial concentration can be investigated by doing adsorption process in many variation of concentrations (from $150 \mathrm{mg} / \mathrm{L}$ until $400 \mathrm{mg} / \mathrm{L}$ ) for 40 minutes. From this process, capacity of adsorption can be determined. At concentration of 0-150 pmm, capacity increased very sharp. It caused by the increasing of mass gradient between solution and 
adsorbent. Thus, $\mathrm{Pb}$ (II) can easily move from solution to adsorbent surface [13]. Up to $150 \mathrm{mg} / \mathrm{L}$, adsorption capacity was slowly increase. Start from $250 \mathrm{mg} / \mathrm{L}-300 \mathrm{mg} / \mathrm{L}$, graphs tend to be stable. It assumpted that at this concentration, the first equilibrium of adsorption was reached. After $300 \mathrm{mg} / \mathrm{L}$, the graph continues to increase. At first equilibrium, can be determined that a chemical adsorption was occured by single layer. But after that there was a physical adsorption involving more than one layer.

The $\mathrm{R}^{2}$ values produced by the Langmuir and Freundlich isotherms were 0.954 and 0.943 , respectively (Table 2). The $\mathrm{Q}_{0}$ parameter describes the maximum adsorption capacity in the monolayer layer. The value of $\mathrm{Q}_{0}$ was $51.02 \mathrm{mg} / \mathrm{g}$. This shows that for every 1 gram of $\mathrm{PANI} / \mathrm{SiO}_{2}$ maximally absorb as much as $51.02 \mathrm{mg} \mathrm{Pb}$ (II). When crossing the limit, the monolayer layer will saturate. Kf denotes Freundlich's constant corresponding to the adsorption capacity ${ }^{[11]}$. When the value of $1 / n \neq 1$, the value of $K f$ will be influenced by the value of $q$ and concentration $(C)$.

The 1 / $\mathrm{n}$ value obtained from the adsorption process of $\mathrm{Pb}$ (II) by $\mathrm{PANI} / \mathrm{SiO}_{2}$ was 2,127 . This shows the strong intermolecular attraction in the adsorbent layer. Although the adsorption of $\mathrm{Pb}$ (II) can occur physically and chemically, when viewed from the value of $\mathrm{R}^{2}$, the more dominant adsorption occurs chemically by forming bonds of chemical compounds between PANI/SiO $\mathrm{Pb}$ (II) active groups. Karthik and Meenakshi (2014) explained that the $\mathrm{PANI} / \mathrm{SiO}_{2}$ composite will bind the metal to the amine group present in PANI.

\section{Conclusion}

The optimum contact time of $\mathrm{Pb}$ (II) adsorption by $\mathrm{PANI} / \mathrm{SiO}$ reached at 40 minutes and optimum adsorption capacity reached at concentration of $250 \mathrm{mg} / \mathrm{L}$. Meanwhile, kinetic model followed pseudo second order with rate constant $0.0124 \mathrm{~g} / \mathrm{mg}$.min. Isoterm adssorption followed Langmuir model with Langmuir's constant (b) was $0,013 \mathrm{l} / \mathrm{mg}$ and monolayer capacity 51.02 $\mathrm{mg} / \mathrm{g}$.

\section{Reference}

[1] Lim A.P., Aris A.Z., A Review on Economically Adsorbents on Heavy Metals Removal in Water and Wastewater, rev. Environ biotechno.2013.

[2] M.Nadeem, R. Nadeem, H.U. Nadeem, S.S. Shah, Accumulation of lead and Cadmium in different Organs of Chicken, Pak. J.Sci. Res. 57 (2005) 71.

[3] Karthik R., Meenakshi S., 2014, Removal of Hexavalent Chromium Ions Using Polyaniline/silica gel Composite, journal of Water Process Engiineering, 1(2014)37-45.

[4] Ayad M.M and Nasr A.A., Anionic Dye (Acid Green 25) Adsorption from Water by Using Polyaniline nanotubes salt/silica Composite, Journal of Nanostructure in Chemistry, 3(3), 2012.

[5] Niu Z., Yang Z., Lu Y., Han C.C., Polyaniline-Silica Composite Conductive Capsules and Hollow Spheres, advance function material, 12(13), 2011.

[6] Ayad M.M and Zaki E.A., Synthesis and Characterization of Polyaniline Films using Fenton Reagent, Journal of Applied Polymer Science, 110 (6): 3410-3419, 2008.

[7] Buhani, Suharso, Sembiring Z., Biosorption of Metal Ions Pb(II), $\mathrm{Cu}$ (II), And Cd(II) on Sargassum duplicatum Immobilized Silica Gel Matrix, 6(3): 245-250, 2006.

[8] Safitri, M.N., Sintesis Silika Gel Fasa Terbalik untuk Kromatografi Kolom dari Limbah Kaca, Universitas Tanjungpura, Fakultas Matematika dan Ilmu Pengetahuan Alam, Pontianak, 2012,(Skripsi). 
[9] Khairi S., Fathony Z., Radhiansyah L.Y., Akbar A.Y., Arryanto Y., Sutarno, Sudrajat H., Sintesis Material Komposit Modified Clay-Polianilin Tersulfonasi (MC-SPANI) sebagai Elektrolit pada Proton Exchange Fuel Cell (PEFC), Universitas Gajah Mada, Yogyakarta, 2009.

[10] Ho, Y. S., dan Mckay, G., Pseudo-second Order Model for Sorption Processes, Pro. Biochem., 34, 451-465, 1999.

[11] Foo K.Y., Hameed B.H., Insights Into the Modeling of Adsorption Isotherm System, Chemical Engineering, 156: 2-10, 2010.

[12] Kurniawati P., Wiyantako B., Kurniawan A., Purbaningtias T.E., Kinetic Study of $\mathrm{Cr}(\mathrm{VI})$ Adsorption on Hydrotalcite Mg/Al with Molar Ratio 2:1, EKSAKTA, 1-2(13): 11-21, 2013. 